\title{
Frasa Nominal dalam Kalimat Berbentuk Susun Balik pada Bahasa Tontemboan
}

\author{
Ferry Hertog Mandang \\ Jurusan Pendidikan Bahasa dan Sastra Indonesia, Fakultas Bahasa dan Seni Universitas Negeri \\ Manado \\ ferrymandang@unima.ac.id
}

\begin{abstract}
Abstrak. Frasa nominal adalah frasa yang intinya adalah nomina. Frasa nomina sangat banyak ditemukan dalam bahasa Tontemboan terutama dalam kalimat. Penelitian ini akan menyoroti masalah: a) bagaimana bentuk-bentuk frasa nomina dalam kalimat bahasa Tontemboan yang strukturnya berbentuk susun balik; b) fungsi-fungsi frasa nominal bahasa Tontemboan, serta c) makna apa saja yang dimunculkan frasa nominal bahasa Tontemboan dalam kalimat susun balik. Metode yang digunakan dalam penelitian ini adalah metode perluasan atau ekspansi serta permutasi atau pembalikan. Metode perluasan sangat cocok menguji apa suatu konstruksi frasa nominal atau tidak, sedangkan permutasi atau pembalikan urutan untuk menguji kalimat apa memenuhi ketatabahasaan bahasa Tontemboan atau tidak, karena pula kalimat bahasa Tontemboan selalu diawali oleh predikat. Hasil penelitian yang dilakukan memperlihatkan bahwa dari segi bentuk frasa nominal bahasa Tontemboan terdiri dari: a) frasa nominal koordinatif dihubungkan oleh kata wo 'dan' serta ka 'pa 'atau' dan $o$ 'serta'; b) frasa nominal distributif; dan c) frasa nominal apositif. Fungsi frasa nominal dalam kalimat dapat berwujud sebagai fungsi subjek, predikat, objek dan keterangan. Segi makna frasa nominal bahasa Tontemboan dapat bermakna: pelaku, sasaran, pengalaman, peruntung, alat, tempat dan waktu. Semua bentuk, fungsi dan makna ditemukan dalam kalimat susun balik atau disebut inversi bahasa Tontemboan karena strukturnya yang demikian.
\end{abstract}

Kata Kunci: Frasa Nominal, Bahasa Tontemboan

\section{PENDAHULUAN}

Bahasa Tontemboan adalah salah satu bahasa daerah di Minahasa yang hingga kini masih tetap dipakai oleh masyarakat penuturnya dalam berkomunikasi sehari-hari. Wilayah penutur bahasa Tontemboan paling besar dibanding bahasa daerah lainnya yang tersebar di Minahasa seperti bahasa Touluur, bahasa Tonsea, bahasa Tombulu atau bahasa Tonsawang. Demikian juga jumlah penuturnya lebih banyak dari yang lainnya.

Kendati intensitas pemakainya mengalami penurunan seperti halnya bahasa daerah lainnya di Minahasa, namun bahasa Tontemboan masih tetap bertahan terutama di kalangan orang tua. Di samping sebagai kepribadian yang merupakan unsur pendukung dan pengembang kebudayaan daerah, bahasa Tontemboan juga menjadi penunjang dan unsur bahasa nasional. Dengan demikian betapa pentingnya menjaga kelestarian bahasa daerah seperti bahasa Tontemboan, agar tidak punah ditelan perkembangan zaman.

Seperti halnya bahasa-bahasa lain di dunia, bahasa Tontemboan juga memiliki bidang-bidang kebahasaan, fonologi, morfologi, sintaksis dan semantik. Sintaksis sebagai kajian yang menyoroti masalah kalimat dianggap penting karena di dalamnya dikaji berbagai aspek seperti pembentuk kalimat, klausa bahkan unsur terkecil dalam tataran kalimat yakni frasa. Walaupun frasa dikatakan unsur terkecil dalam tataran kalimat, namun demikian dapat berperan secara maksimal baik sebagai konstituen pembentuk kalimat bahasa Tontemboan maupun dalam kaitan dengan fungsinya. Salah satu jenis frasa yang cukup mendapat perhatian yang besar adalah frasa nominal yang termasuk frasa endosentrik. Adapun bentuk frasa nominal yang intinya adalah nomina sangat berpeluang mengisi fungsi-fungsi dalam kalimat baik subjek, predikat, objek, pelengkap dan keterangan. Frasa nominal sebagai bagian dari frasa endosentrik sangat besar peranannya dalam kalimat. Dalam kaitannya dengan kategori, 
frasa nominal biasanya menduduki kelas nomina karena memang terbentuk dari nomina. Sedangkan dari sudut peran, frasa nominal biasanya berperan pelaku, pengalaman atau sasaran dan sebagainya.

Perihal struktur kalimat, bahasa Tontemboan memiliki keunikannya, karena jika pada banyak bahasa di dunia umumnya berpola S-P-O-K (Subjek-Predikat-Objek-Keterangan), pada bahasa Tontemboan polanya berbentuk susun balik karena kalimat-kalimatnya diawali dengan predikat kemudian diikuti oleh unsur-unsur lainnya baik subjek, objek, keterangan atau pelengkap dan ini berlaku untuk seluruh kalimat yang digunakan.

Contoh : 1) Mangě am binang kami wava (P-Ket-S)

'Pergi ke Manado kami semua'

(Kami semua pergi ke Manado)

2) Maěma im balě sěila teloo metuari

'Membuat rumah mereka tiga bersaudara'

(Mereka tiga bersaudara membuat rumah)

Menangko'-ngangko't elu to va an g wo 'ba s

'Berteriak-teriak tiga anak muda pria tadi malam'

(Tiga anak muda berteriak-teriak tadi malam)

Beberapa contoh di atas ini semakin menguatkan indikasi adanya pola susun balik dalam kalimat bahasa Tontemboan. Jadi dapat dipastikan bahwa kalimat susun balik selalu diawali dengan predikat kemudian diikuti oleh subjek, objek ataupun keterangan. Dalam hal ini tinggal menyesuaikan dengan prioritas yang diinginkan oleh penyusun kalimat sera struktur kalimat bahasa Tontemboan yang berterima. Sedangkan frasa nominal yang mengisi berbagai fungsi dalam kalimat dapat terbentuk dari dua, tiga, empat kata seperti pada contoh 1), 2) dan 3), subjek kalimat diisi oleh frasa nominal yakni : kami waya 'kami semua', seila telu metuari 'mereka tiga bersaudara' dan telu toyaang wo'bas tuama 'tiga anak muda pria.'

Diharapkan dengan penelitian ini dapat diketahui: bagaimanakah bentuk, fungsi dan makna pada frasa nominal dalam kalimat berpola susun balik bahasa Tontemboan.

\section{METODE}

Adapun metode yang digunakan dalam penelitian ini adalah metode perluasan atau ekspansi serta metode permutasi atau pembalikan urutan (Subroto, 2007:82, 89). Metode perluasan sangat cocok digunakan untuk menentukan sebuah konstruksi yang termasuk frasa nominal atau tidak. Suatu konstruksi yang memiliki kriteria gabungan dua kata atau lebih, tidak berciri konstruksi kalimat, dapat mengisi fungsi dalam klausa serta memiliki distribusi yang sama dengan kata nominal. Keraf (1991) dalam Parera (1993) pada gabungan ini dapat diperluas dengan memasukkan kata-kata tertentu di antara kata-kata yang bergabung secara implisit itu. Sedangkan konstruksi kalimat ............ dengan menerapkan teknik permutasi atau pembalikan urutan, namun memenuhi pola ketatabahasaan sebagaimana yang dimiliki oleh pola kalimat bahasa Tontemboan. Dengan demikian sistem pembalikan atau permutasi dalam memunculkan kalimat-kalimat dalam bahasa Tontemboan yang diwarnai oleh sistem susun balik atau mengawali sebuah kalimat dengan dimulai oleh fungsi predikat yang disusul oleh fungsi-fungsi yang lain.

Penelitian frasa nominal bahasa Tontemboan bersifat kuantitatif. Data yang dianalisis adalah data masa kini. Butir-butir data digolongkan dalam dua jenis yakni data primer berbentuk lisan serta sekunder berwujud tulisan seperti buku-buku yang diterbitkan pada masa kini terutama yang berhubungan dengan frasa nominal.

Data penelitian diperoleh lewat rekaman hasil wawancara yang dilakukan dengan Teknik elistasi yakni memancing pemakaian bahasa pada informan melalui pertanyaan-pertanyaan terarah. Populasi penelitian adalah bahasa Tontemboan yang tersebar di Minahasa. Sampel penelitian adalah penutur bahasa Tontemboan dengan alasan penutur bahasa Tontemboan bersifat homogen artinya karakteristik penggunaan bahasa Tontemboan di tempat yang lain. Dari sampel ini terpilihlah tiga orang 
sebagai informan yang diambil secara acak. Informan diambil di desa Tolok, Tonsewer dan Impok Kecamatan Tompaso.

\section{HASIL DAN PEMBAHASAN}

Berdasarkan penelitian yang dilakukan diperoleh hasil sebagai berikut:

\section{A. Jenis-jenis Frasa Nominal Bahasa Tontemboan}

\section{Frasa Nominal yang Koordinatif Dihubungkan kata wo 'dan'}

Contoh:

a. Ma'tawoi an somoi imbalĕ papa wo simama 'Bekerja di belakang rumah ayah dan ibu' (Ayah dan ibu bekerja di belakang rumah)

b. Ma' suub im běnĕ sěwĕwĕnĕ wa sĕtuama kaawimadasa

c. 'Memotong padi wanita dan pria kemarin dulu' (Wanita dan pria memotong padi kemarin) Ma'kantar mebali-wali sĕwo'bas wo sěmatua 'Menyanyi bersama-sama kaum muda dan kamu tua' (Kaum muda dan kaum tua menyanyi bersama-sama)

Semua bentuk bergaris tebal pada kalimat a), b) dan c) adalah frasa nominal koordinatif karena terdapat dua kata yang setara dihubungkan kata wo 'dan'.

Dihubungkan kata ka'pa 'atau'
Contoh:
a. Naspalem lalan wangker ka'pa těkĕe' an do'ong 'sudah diaspal jalan lebar di atau sempit di kampung' (jalan lebar dan sempit di kampung sudah diaspal)
b. Amé'jam en tu'tuk paso'ka'pa uson 'Sudah di meja nasi panas atau dingin' (Nasi yang panas atau dingin sudah di meja)
c. Indomem em punti wowos ka'pa mata 'Ambil saja pisang itu masak atau mentah' (Ambil saja pisang itu masak atau mentah)

Semua bentuk bergaris tebal pada kalimat a), b) dan c) termasuk frasa nominal koordinatif karena terdapat dua bentuk setara yang dihubungkan kata $\mathrm{ka}$ ' $\mathrm{pa}$ 'atau'. Dihubungkan kata $o$ 'serta'
Contoh:
a. Winětěngemla en ta'be o katanaan an Sonděr 'Sudah dibahagi sawah serta ladang di Sonder' (Sawah dan ladang di Sonder sudah dibahagi)
b. Malali sa'bel o pacol sakamo mangě anuma
'Bawalah parang serta cangkul kalau kamu pergi ke kebun' (Jika kamu pergi ke kebun bawalah parang dan cangkul)
c. Ma'lemě sĕ tou sumakit si tanta o siom
'Mengobati orang sakit bibi serta paman'
(Bibi serta paman mengobati orang sakit)

\section{Frasa Nominal Atributif}

Contoh:

a. Malěwo'em an lalan aspal nema' an do'ong 'Rusaklah jalan aspal yang dibuat di kampung' (Jalan aspel yang dibuat di kampung sudah rusak) Ma'siwo tu'tu' pulut rindang si oli ka'awi 
'Memasak nasi ketan merah Oli kemarin'

(Oli memasak nasi ketan merah kemarin)

c. Muntep ruma saki umum pusat si tětě Enoch kawengi

'Masuk rumah sakit umum pusat kakek Enoch tadi malam'

(Kakek Enoch dirawat di rumah sakit umum pusat tadi malam)

Bentuk-bentuk yang bercetak tebal adalah frasa nominal atributif karena pada bentuk bercetak tebal terdiri atas bentuk inti yang berkelas kata benda dan penjelasnya atau atribut.

\section{Frasa Nominal Apositif}

Contoh:

a. Tou Tonsea, O. Dondokambey, gubernur Sulawesi Utara

'Orang Tonsea, O. Dondokambey, gubernur Sulawesi Utara'

(Gubernur Sulawesi Utara, O. Dondokambey orang Tonsea)

b. Ma'kuliah an Unsrat, Herlan toyaang kaka'tan

'Berkuliah di Unsrat Herlan, anak yang bungsu'

(Herlan, anak yang bungsu kuliah di Unsrat)

c. Tayang keli uma i Dorkas, kakak i Erat

'Jauh benar kebun dari Dorkas kakak dari Erat'

(Jauh benar kebun milik Dorkas, kakak dari Erat)

\section{B. Fungsi Frasa Nominal Bahasa Tontemboan}

Fungsi frasa nominal bahasa Tontemboan dapat kita lihat seperti berikut:

\section{Berfungsi sebagai Subjek Kalimat}

Contoh :

a. Wangker terang em balĕ i Atos an Dumoga (P-S-K)

'Besar betul rumah Atos di Dumoga'

(Besar sekali rumah dari Atos di Dumoga)

b. Sumino tu'tu' balě wěwěnĕ o tuama (P-O-K-S)

'Memasak nasi di rumah wanita dan pria'

(Wanita dan pria memasak nasi di rumah)

c. Kumiit an kuntung se mangalitou o mangaken kandian (P-O-S-K)

'Pergi ke gunung para pemuda dan pemudi esok lusa'

(Para pemuda dan pemudi pergi ke gunung besok lusa)

Bentuk: $\quad$ a. balě $i$ Atos, 'rumah dari Atos'

b. wěwěnĕ o tuama, 'wanita dan pria'

c. mangalitou o mangaken kandian 'pemuda dan pemudi'

Bentuk kalimat a), b) dan c) adalah frasa nominal, yang berfungsi subjek pada kalimat-kalimat di atas. Sedangkan posisinya dalam kalimat biasanya sesudahnya predikat.

\section{Berfungsi sebagai Predikat Kalimat}

Contoh:

a. Rangka'terang ang kuntung Kelabat an Airmadidi

'Tinggi sekali gunung Kelabat di Airmadidi'

(Gunung Kelabat tinggi sekali letaknya di Airmadidi)

b. Petani tē'ěs si mom Ibor kakak i Repi

c. 'Petani rajin si bapak Ibor kakak dari Repi'

(Bapak Ibor seorang petani rajin kakak dari Repi)

Kemel O rangka'se Onibala an do'ong

'Gemuk dan tinggi keluarga Onibala di kampung'

(Keluarga besar Onibala tinggi-tinggi badannya di kampung) 
Bentuk-bentuk bergaris bawah pada kalimat $a, b$, dan $c$ adalah frasa nominal yang berfungsi predikat kalimat. Dalam bahasa Tontemboan fungsi predikat selalu berada pada posisi awal kalimat sebagaimana sistem pada bahasa Tontemboan.

\section{Berfungsi sebagai Objek Kalimat}

Contoh: $\quad$ a. Ma'siwo wĕnĕ weru si Thelma kawo'ondo am bale 'Memasak padi baru si Thelma tadi pagi di rumah' (Thelma memasak beras baru tadi pagi di rumah)

b. Ma'piara asu wuling wangker si Ogi a rumah 'Si Ogi memelihara anjing hitam besar di kebun' (Ogi memelihara anjing hitam besar di kebun)

c. Maěma' punti goreng wowos si mamaku an doong 'Membuat kue pisang goreng masa ibu di kampung' (Ibu membuat kue pisang goreng masak di kampung)

Bentuk-bentuk bergaris bawah pada kalimat a, b, dan c adalah frasa nominal yang menduduki fungsi objek kalimat. Biasanya posisi objek dalam kalimat berada sesudah predikat, sebagaimana kita pahami bahwa fungsi predikat biasanya menjelaskan fungsi objek.

\section{Berfungsi sebagai Keterangan Kalimat}
Contoh:
a. Ma'kan kapaya anuma wua' së'la metuari
'Memakan pepaya di kebun buah mereka bersaudara'
(Mereka bersaudara memakan pepaya di kebun buah)
b. Ma' tulis surat si Renny ang kantas welad
'Menulis surat si Renny di kertas lebar'
(Renny menulis surat di kertas lebar)
c. Mangě anuma sĕ'la maamang mamo'ondo terang
'Pergi ke kebun ayah dan anak pagi-pagi sekali'
(Ayah dan anak pergi ke kebun pagi-pagi sekali)

Bentuk-bentuk bergaris bawah pada kalimat a, b, dan c adalah frasa nominal yang menduduki fungsi keterangan dalam kalimat. Sering keterangan terletak sesudah subjek kalimat, karena biasanya fungsi keterangan merupakan sesuatu yang dilakukan subjek atau perihal rentang subjek baik tempat, waktu serta hal-hal lain.

\section{Fungsi Frasa Nominal dalam Kalimat}

Frasa nominal bahasa Tontemboan dapat berperan sebagai berikut:

\section{Pelaku}

Contoh: $\quad$ a. Pa'tawoien i Piter rantoi ta'bě $i$ George Rantung

'Yang dikerjakan Piter tinggi adalah sawah George Rantung'

(Sawah milik George Rantung dikelola oleh Piter tinggi)

Ma'bulingaum si ko'kok kulo' umintud kaawii

b. 'Mulai bertelur ayam putih sejak kemarin'

(Sejak kemarin ayam putih mulai bertelur)

c. Wawete'em ang kuntang Soputan kawengi pě'bo

'Sudah meletus gunung Soputan dari tadi malam'

(Gunung Soputan sudah meletus dari tadi malam) 
Bentuk-bentuk bergaris bawah adalah frasa nominal bahasa Tontemboan yang bermakna pelaku dalam kalimat. Peran pelaku di sini dapat berbentuk benda hidup seperti manusia atau hewan, juga benda mati seperti gunung yang bertindak seperti benda hidup.

\section{Sasaran}

Contoh :

a. Ma'pinjam sa'bel lambot si Utu' asi Erens

'Meminjam parang panjang si Utu' paka Erens'

(Utu' meminjam parang yang panjang pada Erens)

b. Ma'linga pidato presiden kami di radio

'Mendengar pidato presiden kami di radio'

(Kami mendengar pidato presiden di radio)

c. Kumuris im po'po' matu'a Empy an somoi im bale

'Mencukur kelapa tua Empy di belakang rumah'

(Empy mencukur kelapa yang tua di belakang rumah)

Bentuk-bentuk bergaris bawah adalah frasa nominal bahasa Tontemboan yang bermakna seseorang dalam kalimat. Sasaran di sini adalah sesuatu yang menjadi maksud pelaku atau berhubungan dengan pelaku.

\section{Pengalaman}

Contoh :

a. Sinekitan po'otna si Dolop kete'da im bengi

'Sakit perutnya si Dolop tadi malam'

(Dolop sakit perutnya tengah malam)

b. Luméwo' in atep imbale reges lëwo' ka'awi

'Merusak atap rumah angin kencang kemarin'

(Angin kencang merusak rumah kemarin)

c. Rune'ba em pohon wangker sementara se'tou tumekel

'Roboh pohon itu sementara orang tidur'

(Pohon itu roboh sementara orang tidur)

Bentuk bergaris bawah adalah frasa nominal bahasa Tontemboan yang bermakna pengalaman dalam kalimat. Pengalaman di sini adalah sesuatu yang dialami subjek baik benda hidup maupun benda mati.

\section{Peruntung}

Contoh :

a. Měe'ě ro'it sia a sě toyaang tuama o wěwěne

'Memberi uang dia pada anak-anak pria dan wanita'

(Ia memberi uang kepada anak-anak pria dan wanita)

b. Měe ěi an do'ong si kaka'na matu'a ka'awii pě'bo

'Datang di kampung kakaknya tertua sejak kemarin'

(Kakaknya yang tertua datang di kampung sejak kemarin)

c. Masalěk terang si tětě lumelěk an ranopaso'-

'Suka sekali si kakek mandi di air yang panas'

(Suka sekali si kakek mandi di air yang panas)

Bentuk bergaris bawah di atas adalah frasa nominal bahasa Tontemboan yang bermakna peruntung dalam kalimat. Contoh-contoh di atas menandakan bahwa subjek mendapat sesuatu yang menguntungkan pada kalimat-kalimat di atas.

Alat

Contoh : $\quad$ a. Marěng sě ila sumake kapal terbang

'Pulang mereka menggunakan kapal terbang'

(Mereka pulang menggunakan kapal terbang)

b. Ma'pakě sa'bel lambot si tětě Cengky 


\section{'Menggunakan parang yang panjang kakek Cengky' \\ (Kakek Cengky menggunakan parang yang panjang) \\ c. Makě kaca mata si Joula kawengi \\ 'Menggunakan kacamata si Joula tadi malam' \\ (Joula memakai kaca mata tadi malam)}

Bentuk-bentuk bergaris bawah di atas adalah frasa nominal bahasa Tontemboan yang bermakna alat. Pada contoh ini, objek kalimat memperlihatkan bahwa sesuatu yang digunakan dalam aktivitas/kegiatan berbentuk alat.

\section{Tempat}

Contoh :
a. Masiar kami kaawii makasa am bukit kasih
'Pesiar kami kemari dulu di bukit kasih'
(Kami pesiar ke bukit kasih kemarin dulu)
b. Maе̌ma' im patětěan si papa an doyongan lekĕk
'Membuat jembatan ayah saluran kecil'
(Ayah membuat jembatan di saluran kecil)
c. Mat'tulis si ksks sm mĕ'ja werong kawengi
'Menulis si kakak di meja bulat tadi malam'
(Kakak menulis di meja bulat tadi malam)

Bentuk-bentuk bergaris bawah di atas adalah frasa nominal bahasa Tontemboan yang bermakna tempat. Di sini memperlihatkan bahwa subjek melakukan aktivitasnya di tempat tersebut (frasa nominal).

Waktu
Contoh :
a. Museb měěi in tolaang kaya yana ta'un lalu
'Menanam kami ketela pohon itu tahun yang lalu'
(Kami menanam ketela pohon itu tahun yang lalu)
b. Ciarla si asu mate kaawi makase
'Dikuburkan anjing itu kemarin dulu'
(Mereka menguburkan anjing itu kemarin dulu)
c. Tumulisi in surat si Evy kaawii imbengki
'Ditulis surat itu oleh Evy tadi malam'
(Surat itu ditulis Evy tadi malam)

Bentuk-bentuk bergaris bawah di atas adalah frasa nominal bahasa Tontemboan yang bermakna waktu. Maksudnya melakukan subjek melakukan aktivitas tersebut sesuai dengan waktu yang dinyatakan kalimat-kalimat itu.

\section{KESIMPULAN}

Berdasarkan pembahasan di depan dapatlah dikatakan bahwa frasa nominal bahasa Tontemboan adalah sejenis frasa yang memiliki umur pusat nominal. Frasa nominal bahasa Tontemboan dapat dianalisis dari aspek bentuk, fungsi dan makna dalam kalimat. Dari segi bentuk, frasa nominal bahasa Tontemboan memiliki bentuk : a) frasa nominal yang koordinatif ditandai oleh dihubungkannya dengan kata wo 'dan'; kata ka'pa 'atau' dan kata $o$ 'serta'; b) frasa nominal atributif; dan c) frasa nominal yang apositif. Dari segi fungsi, frasa nominal bahasa Tontemboan dapat berfungsi sebagai subjek, predikat, objek dan keterangan dalam kalimat. Makna frasa nominal dalam kalimat dapat berupa makna pelaku, sasaran, pengalaman, peruntung, alat, tempat dan waktu. Frasa nominal bahwa Tontemboan muncul pada kalimat-kalimat yang polanya berbentuk susun balik atau selalu diawali oleh predikat kalimat atau kalimat inversi. Frasa nominal yang ada dapat terdiri atas dua kata tiga kata bahkan ada yang lebih. 


\section{DAFTAR PUSTAKA}

Alwi, Hasan. 1990. Modalitas dalam Bahasa Indonesia. Jakarta: Djambatan. , 2007. Kamus Besar Bahasa Indonesia. Jakarta: Balai Pustaka. 2000. (Peny.) Tata Bahasa Buku Bahasa Indonesia. Jakarta: Balai Pustaka.

Chaer, A., 1993. Gramatika Bahasa Indonesia. Jakarta: Rineka Cipta. , 2000. Linguistik Umum. Jakarta: Rineka Cipta. 2008. Morfologi Bahasa Indonesia. Jakarta: Rineka Cipta.

Kridalaksana, H., 2002. Struktur, Kategori dan Fungsi dalam Teori Sintaksis. Jakarta: Universitas Katolik Atmajaya. , 2008. Kamus Linguistik. Jakarta: Gramedia Pustaka Utama. Parera, J.D. 2007. Sintaksis. Jakarta: Gramedia.

Ramlan, M. 2015. Ilmu Bahasa Indonesia Sintaksis. Yogyakarta: UD Karyono. Putrayasa, I. Gede. 2009. Tata Kalimat Bahasa Indonesia. Bandung: Refika Aditama.

Samsuri. 1989. Tata Kalimat Bahasa Indonesia. Jakarta: Sastra Hudaya.

Slamet, Mulyana. 1969. Kaidah Bahasa Indonesia. Ende Flores: Nusa Indah.

Sudaryanto. 1983. Predikat-Objek dalam Bahasa Indonesia. Jakarta: Djambatan.

Sidu, Laode. 2013. Sintaksis Bahasa Indonesia. Unhan Press. 